\title{
ANALISIS LIMBAH CETAKAN LOGAM SEBAGAI BAHAN SUBSTITUSI PENGGANTI AGREGAT HALUS DALAM UPAYA PERBAIKAN KUAT TEKAN BETON
}

\author{
Mujahidin, Tri Mulyono, Nira Nasution
}

\begin{abstract}
Abstrak
The research is aimed to recognized the differences of the pressure durability in the concrete that uses metal mould waste as refined agregat wits $0 \%$, $25 \%, 50 \%, 75 \%$ and $100 \%$ composition toward sand weight and wheither pressure with $25 \%, 50 \%, 75 \%$ and $100 \%$ composition toward sand weight bigger than pressure durability concrete standar with $0 \%$ composition metal mould waste toward the sand weight. This research was done in Material Science Department FMIPA Post Graduated Program Laboratory University of Indonesia in December 2003 an in Material Science Engineering Laboratory of DKI Jakarta in Jalan Let.Jend. Soeprapto Center Jakarta at Pebruary to Mei 2004.

The methodology that is used for this research is the experimentalresearch methodology. Research population is eubic concrete material tests as many as 60 cubes for five threatments. First hypothesis tests with varians analyse one direction and second hypothesis with T-Tests. Analysis reguirement tests is used normality tests and homogeneity tests that produce normal distribution and homogen data.

First hypothesis to get $F_{\text {hitung }} \geq F_{\text {tabel }}$ or $269,59 \geq 2,51, H_{0}$ is refused and $H_{1}$ is accept. Second hypothesis (a) $H_{0}: \mu_{B}=\mu_{A}$ is obtained $F_{\text {hitung }} \geq$ $F_{\text {tabel }}$ or 7,907 2,68; so $H_{0}$ and $H_{1}$ is refused, second hypothesis (b) $H_{0}: \mu_{C}=$ $\mu_{A A}$ is obtained Fitung $\geq F_{\text {tabel }}$ or $17,41 \geq 2,68$; so $H_{0}$ and $H_{1}$ is refused, second hypothesis (c) $H_{0}: \mu_{D}=\mu_{A}$ is obtained $F_{\text {hitung }} \geq F_{\text {tabel }}$ or $25,08 \geq 2,68$; so $H_{0}$ and $H_{1}$ is refused and second hypothesis (d) $H_{0}: \mu_{E}=\mu_{A}$ is obtained $F_{\text {hitung }} \geq F_{\text {tabel }}$ or $22,41 \geq 2,68$; so $H_{0}$ and $H_{1}$ is refused.

The result of this study are (1) there is different of pressure durability concrete that used metal mould waste as refined agregat with $0 \%, 25 \%, 50 \%$, $75 \%$ and $100 \%$ composition metal mould waste toward sand weight, (2) pressure durability that uses metal mould waste as refined agregat with $25 \%$, $50 \%, 75 \%$ and $100 \%$ composition metal mould waste towards sand weight lower than pressure durability concrete standar with $0 \%$ composition metal mould waste toward the sand weight.
\end{abstract}

Keyword : concrete , pressure durability, metal mould waste

Mujahidin

Alumni Jurusan Teknik Sipil

Fakultas Teknik

Universitas Negeri Jakarta, 13220
Ir. Tri Mulyono, MT

Staf Pengajar Jurusan Teknik Sipil Fakultas Teknik

Universitas Negeri Jakarta, 13220 email : tri_mulyono_sipilunj@yahoo.co.id
Dra. Nira Nasution, ST, M.Pd

Staf Pengajar Jurusan Teknik Sipil

Fakultas Teknik

Universitas Negeri Jakarta, 13220 email : nira22@telkom.net 


\section{PENDAHULUAN}

Agregat adalah campuran mineral yang berfungsi sebagai bahan pengisi pada campuran mortar (adukan) dan beton, terutama pasir sebagai agregat halus. Pasir dan batu harus merupakan bahan yang tahan lama, seperti kwarsa, batu kapur belah atau basalt sehingga mempunyai kekuatan yang tinggi daripada beton (Lawrence H.Van Vlack, 1992, h.526). Ukuran agregat halus bervariasi antara ukuran nomor 4 dan nomor 100 saringan standar Amerika. Agregat halus yang baik harus bebas dari bahan organik, lempung, partikel yang lebih kecil dari saringan nomor 100 atau bahan-bahan lain yang merusak campuran beton. Pasir yang ditambang atau dikeruk untuk bangunan secara kontinyu biasanya meninggalkan bekas-bekas galian atau lubang tanah yang sangat merugikan masyarakat disekitarnya. Jumlah pasir tersebut akan terus berkurang dan mungkin bisa habis karena angka penambangan pasir lebih besar daripada persediaannya.

Pasir dalam bangunan berfungsi sebagai agregat halus, khususnya beton. Agregat biasanya menempati $70 \%$ sampai dengan $75 \%$ dari seluruh volume masa padat beton, sehingga sifat-sifat agregat mempunyai pengaruh yang besar terhadap perilaku beton sesudah mengeras. Agregat bukan hanya mempengaruhi sifat beton, tetapi mempengaruhi juga ketahanan beton (durability) (Chu Kia Wang, 1993, h.7). Beton didapat dari pencampuran bahan-bahan agregat halus dan kasar yaitu pasir, batu, batu pecah atau bahan semacam lainnya. Setelah itu menambahkan secukupnya bahan perekat semen dan air sebagai bahan pembantu guna keperluan reaksi kimia selama proses pengerasan dan perawatan beton berlangsung (Istimawan Dipohusodo, 1996, h.1).

Adukan beton merupakan unsur utama dalam bangunan, sehingga bahan-bahan adukan beton harus dijaga dengan baik serta dicari alternatif lain pengganti bahan bangunan terutama pasir. Untuk memperoleh alternatif tersebut perlu ada kajian bahan-bahan yang bisa memenuhi persyaratan sebagai bahan bangunan.

Pembuatan logam dikota-kota besar atau didaerah industri terus tumbuh dan berkembang dengan pesatnya. Cetakan logam biasanya menggunakan silica, water glass (air kaca) dan semen merah. Pada proses pembuatan cetakan logam terdapat limbah padat berupa sisa-sisa dari pembuatan cetakan logam dan limbah cetakan logam yang gagal atau cacat produksi. Jumlah limbah padat ini akan terus bertambah sehingga memerlukan tempat penimbunan yang cukup luas. Melihat bentuk fisik limbah cetakan logam yang hampir sama dengan pasir, maka ada indikasi kalau limbah ini dapat dimanfaatkan untuk digunakan sebagai agregat halus pada suatu bangunan khususnya beton.

Diharapkan dengan penelitian sumber material yang berbeda yaitu limbah cetakan logam sebagai agregat halus pada kuat tekan beton dengan perbandingan campuran volume semen, limbah cetakan logam dan agregat kasar maka akan didapatkan kekuatan tekan beton minimum. Disamping itu beton yang dihasilkan tentunya sesuai dengan standar kekuatan yang telah ditentukan. 
Berdasarkan latar belakang masalah diatas, maka dapat ditarik identifikasi masalahnya yaitu :

a. Apakah penggunaan limbah cetakan logam sebagai agregat halus dapat mempengaruhi kuat tekan beton?

b. Apakah penggunaan limbah cetakan logam sebagai agregat halus dapat memenuhi persyaratan mutu beton yang telah ditentukan?

c. Apakah ada perbedaan antara kuat tekan beton yang menggunakan limbah cetakan logam sebagai agregat halus dengan kuat tekan beton beton standar yang tanpa menggunakan limbah cetakan logam sebagai agregat halus?

Pada penelitian ini penulis membatasi permasalahannya pada:

1. Pengunaan limbah cetakan logam hanya dengan komposisi $0 \%, 25 \%, 50 \%, 75 \%$ dan $100 \%$ terhadap berat pasir.

2. Penelitian ini dilakukan hanya pada kuat tekan betonnya saja.

3. Kekuatan beton dalam penelitian ini menggunakan standar mutu K-225.

4. Penelitiaan ini menggunakan 5 kelompok perlakuan dengan tiap kelompok perlakuan ada 12 sampel.

5. Metode pencampuran dengan cara volume.

Berdasarkan pembatasan masalah diatas, maka dapat dirumuskan masalahnya sebagai berikut :

a. Apakah ada perbedaan kuat tekan beton yang menggunakan limbah cetakan logam sebagai agregat halus dengan komposisi $0 \%, 25 \%, 50 \%, 75 \%$ dan 100\% limbah cetakan logam terhadap berat pasir?.

b. Apakah kuat tekan beton yang menggunakan limbah cetakan logam sebagai agregat halus dengan komposisi 25\%,50\%,75\% dan 100\% limbah cetakan logam terhadap berat pasir lebih besar dari kuat tekan beton standar dengan komposisi $0 \%$ limbah cetakan logam terhadap berat pasir?

Kegunaan penelitian tentang kuat tekan beton yang menggunakan limbah cetakan logam sebagai agregat halus, yaitu antara lain :

a. Pemanfaatan limbah cetakan logam sebagai agregat halus pada pembuatan beton.

c. Sebagai bahan kajian dalam konstruksi bangunan, khususnya masalah bahan-bahan bangunan.

d. Mengetahui kuat tekan beton yang menggunakan limbah cetakan logam sebagai agregat halus.

e. Dapat menambah keilmuan dan pengembangan pengetahuan khususnya masalah beton bagi mahasiswa Teknik Sipil Fakultas Teknik Universitas Negeri Jakarta. 
Penelitian ini bertujuan untuk mengetahui :

1. Perbedaan kuat tekan beton yang menggunakan limbah cetakan logam sebagai agregat halus dengan komposisi 0\%, 25\%, 50\%, 75\% dan 100\% limbah cetakan logam terhadap berat pasir.

2. Apakah kuat tekan beton yang menggunakan limbah cetakan logam sebagai agregat halus dengan komposisi 25\%,50\%,75\% dan 100\% limbah cetakan logam terhadap berat pasir lebih besar dari kuat tekan beton standar dengan komposisi $0 \%$ limbah cetakan logam terhadap berat pasir.

\section{METODA}

Berdasarkan tujuan penelitian diatas, maka metode yang akan dipakai dalam penelitian ini adalah metode eksperimen.

Adapun variabelnya yaitu :

1. Variabel terikat yaitu nilai kuat tekan beton yang menggunakan limbah cetakan logam sebagai agregat halus.

2. Variabel bebas yaitu beton yang menggunakan komposisi $0 \%, 25 \%, 50 \%, 75 \%$ dan $100 \%$ limbah cetakan logam terhadap berat pasir.

Populasi pada penelitian ini yang menggunakan limbah cetakan logam sebagai agregat halus dengan komposisi 25\%, 50\%, 75\% dan 100\% limbah cetakan logam terhadap berat pasir sebanyak 48 benda uji dari 4 kelompok perlakuan dan beton standar dengan komposisi $0 \%$ limbah cetakan logam terhadap berat pasir sebanyak 12 benda uji dari 1 kelompok perlakuan. Jadi untuk setiap kelompok perlakuan ada 12 benda uji.

Sampel yang digunakan adalah :

a. Sampel utama kelompok benda uji yang menggunakan limbah cetakan logam sebagai agregat halus. Sampel yang digunakan berjumlah 48 benda uji untuk 4 kelompok perlakuan, jadi ada 4 kelompok perlakuan benda uji yaitu dengan komposisi 25\%, 50\%, 75\% dan 100\% limbah cetakan logam terhadap berat pasir.

b. Sampel pembanding yaitu kelompok benda uji yang menggunakan komposisi $0 \%$ limbah cetakan logam terhadap berat pasir sebanyak 12 benda uji untuk satu kelompok perlakuan.

Pengambilan data ini dilakukan dengan menguji kuat tekan benda uji yaitu beton kubus berukuran $15 \mathrm{~cm} \times 15 \mathrm{~cm} \times 15 \mathrm{~cm}$ yang menggunakan pasir dan limbah cetakan logam sebagai agregat halus dengan mesin uji tekan. Penelitian dilakukan pada 5 kelompok perlakuan dengan masing-masing perlakuan dibuat benda uji sebanyak 12 buah. Bentuk atau pola kelompok benda uji dapat dilihat pada Tabel 1 
Tabel 1 Kelompok Perlakuan Penelitian.

\begin{tabular}{|c|c|c|c|c|}
\hline Kelompok A & Kelompok B & Kelompok C & Kelompok D & Kelompok E \\
\hline 1 & 1 & 1 & 1 & 1 \\
2 & 2 & 2 & 2 & 2 \\
3 & 3 & 3 & 3 & 3 \\
4 & 4 & 4 & 4 & 4 \\
5 & 5 & 5 & 5 & 5 \\
6 & 6 & 6 & 6 & 6 \\
7 & 7 & 7 & 7 & 7 \\
8 & 8 & 8 & 8 & 8 \\
9 & 9 & 9 & 9 & 9 \\
10 & 10 & 10 & 10 & 10 \\
11 & 11 & 11 & 11 & 11 \\
12 & 12 & 12 & 12 & 12 \\
\hline
\end{tabular}

Keterangan :

Kelompok $A=$ Kelompok perlakuan dengan komposisi $0 \%$ limbah cetakan logam terhadap berat pasir.

Kelompok B = Kelompok perlakuan dengan komposisi $25 \%$ limbah cetakan logam terhadap berat pasir.

Kelompok C = Kelompok perlakuan dengan komposisi 50\% limbah cetakan logam terhadap berat pasir.

Kelompok D = Kelompok perlakuan dengan komposisi 75\% limbah cetakan logam terhadap berat pasir.

Kelompok $E=$ Kelompok perlakuan dengan komposisi 100\% limbah cetakan logam terhadap berat pasir.

Instrumen yang digunakan adalah seperangkat alat uji kuat tekan beton dan daftar isian yang digunakan untuk mengumpulkan data serta validasi kalibrasi alat penelitian.

\section{Prosedur Penelitian}

\section{Tahap Persiapan}

Pekerjaan dalam penelitian ini adalah menyiapkan bahan-bahan penelitian dan peralatan pengujian. Pengadaan bahan-bahan penelitian antara lain semen, pasir, limbah cetakan logam, agregat kasar dan air. Pengadaan peralatan pengujian seperti timbangan, saringan agregat, cetakan benda uji dan pelengkap lainnya serta mempelajari bagaimana penggunaan alat tersebut.

\section{Pemeriksaan bahan}

a. Semen tidak perlu di uji karena sudah memenuhi SNI No. 013-81 dan penelitian ini menggunakan semen type I.

b. Pasir yang sudah dicuci meliputi pemeriksaan gradasi agregat, berat jenis, penyerapan air, kadar lumpur, berat isi, indek kekerasan butir dan zat-zat yang yang merusak. 
c. Limbah cetakan logam yang sudah dicuci meliputi pemeriksaan gradasi agregat, berat jenis, penyerapan air, kadar lumpur, berat isi, indek kekerasan butir dan zat-zat yang yang merusak.

d. Agregat kasar yang sudah dicuci meliputi pemeriksaan gradasi agregat, berat jenis, penyerapan air, kadar lumpur dan berat isi.

e. Air tidak perlu di uji karena menggunakan air PAM yang sudah ada di laboratorium.

\section{Pembuatan benda uji}

Pembuatan benda uji yaitu mencampurkan bahan-bahan beton sesuai dengan komposisi perbandingannya yang langsung diikuti pembuatan benda uji beton berbentuk kubus dengan ukuran $15 \mathrm{~cm} \times 15 \mathrm{~cm} \times 15 \mathrm{~cm}$. Langkah-langkah pembuatan benda uji beton adalah sebagai berikut:

a. Mencari kombinasi analisa ayakan dan berat jenis agregat

b. Membuat rencana campuran beton mutu K-225.

c. Mempersiapkan bahan dan peralatan pembuatan benda uji seperti semen, pasir limbah cetakan logam, air, kerikil, molen, alat penggetar atau tusukan, tempat adukan, cetakan kubus, alat pengukur slump dan alat pelengkap lainnya.

d. Menimbang bahan-bahan beton sesuai dengan desain perhitungan untuk setiap perlakuan.

e. Menghidupkan alat pemutar beton atau molen.

f. Penuangan bahan-bahan beton secara bertahap ke alat pemutar beton atau molen.

g. Pengadukan beton atau pemutaran molen sampai adukan beton sudah matang.

h. Mengukur nilai slump.

i. Penuangan adukan beton ke tempat adukan beton.

j. Penuangan adukan beton ke cetakan beton kubus sambil dipadatkan dengan alat tusuk atau cetakan kubus digetarkan di alat penggetar.

k. Penyimpanan cetakan kubus yang sudah berisi adukan beton ke tempat yang aman.

I. Pembongkaran cetakan kubus dan sekaligus merendam benda uji beton ke tempat perendaman benda uji.

m. Membersihkan peralatan pembuatan beton yang sudah dipakai. 


\section{Teknik Analisa Data}

Analisa data untuk hipotesis I dengan menggunakan uji normalitas, uji homogenitas dan uji analisa varians satu arah. Analisa data untuk hipotesis II (a), II (b), II (c) dan II (d) dengan menggunakan uji normalitas, uji homogenitas dan uji T.

\section{Hipotesis Statistik.}

1) Hipotesis I

$\mathrm{H}_{0}: \mathrm{B}=\mathrm{C}=\mathrm{D}=\mathrm{E}$

$\mathrm{H}_{1}: \mathrm{B} \neq \mathrm{C} \neq \mathrm{D} \neq \mathrm{E}$

\section{Keterangan :}

$\mathrm{B}=$ Kelompok perlakuan dengan komposisi $25 \%$ limbah cetakan logam.

$\mathrm{c}=$ Kelompok perlakuan dengan komposisi $50 \%$ limbah cetakan logam

$\mathrm{D}=$ Kelompok perlakuan dengan komposisi $75 \%$ limbah cetakan logam.

$E=$ Kelompok perlakuan dengan komposisi 100\% limbah cetakan logam.

2) Hipotesis II
(a) $\mathrm{H}_{0}: \mathrm{B}=\mathrm{A}$,
(b) $\mathrm{H}_{0}: \mathrm{C}=\mathrm{A}$,
$\mathrm{H}_{1}: \mathrm{B}>\mathrm{A}$,
$\mathrm{H}_{1}: \mathrm{C}>\mathrm{A}$
(c) $\mathrm{H}_{0}: D=A$,
(d) $H_{0}: E=A$
$H_{1}: D>A$,
$H_{1}: E>A$

\section{Keterangan:}

$A=$ Kuat tekan rata-rata beton standar dengan komposisi $0 \%$ limbah cetakan logam terhadap berat pasir.

$\mathrm{B}=$ Kuat tekan rata-rata beton yang menggunakan limbah cetakan logam sebagai pasir dengan komposisi 25\% terhadap berat pasir.

$c=$ Kuat tekan rata-rata beton yang menggunakan limbah cetakan logam sebagai pasir dengan komposisi $50 \%$ terhadap berat pasir.

$\mathrm{D}=$ Kuat tekan rata-rata beton yang menggunakan limbah cetakan logam sebagai pasir dengan komposisi 75\% terhadap berat pasir.

$\mathrm{E}=$ Kuat tekan rata-rata beton yang menggunakan limbah cetakan logam sebagai pasir dengan komposisi 100\% terhadap berat pasir. 


\section{HASIL DAN PEMBAHASAN}

\section{Deskripsi Data}

Dalam penelitian data merupakan faktor penentu dalam menentukan kesahihan dankevalidan suatu penelitian. Dengan data maka akan diproses dari hasil penelitian dengan ilmu statistik. Pada penelitian ini, limbah cetakan logam (ICl) digunakan sebagai agregat halus dengan menggunakan bentuk kubus sebagai benda ujinya. Adapun kombinasi komposisi limbah cetakan logam sebagai bahan substitusi pengganti agregat halus yaitu 0\%, 25\%, 50\%, 75\% dan 100\% limbah cetakan logam terhadap berat pasir.

Pada kelompok pengujian diatas setelah dilakukan serangkaian penelitian mengenai uji bahan dan pembuatan benda uji serta perawatan benda uji selanjutnya dilakukan pengujian ukuran dan berat benda uji yang terus dilakukan pengujian kuat tekan pada benda uji tersebut.

\section{Pemeriksaan ukuran dan berat benda uji beton}

Benda uji yang sudah jadi dan siap untuk diuji, sebelumnya dilakukan pemeriksaan ukuran dan berat benda uji. Hasil rata-rata pemeriksaan ukuran dan berat benda uji tertera pada Tabel 2.

Tabel 2 Hasil Rata-rata Ukuran dan Berat Benda Uji.

\begin{tabular}{|c|c|c|c|c|}
\hline $\begin{array}{l}\text { Kelom } \\
\text {-pok }\end{array}$ & Komposisi Campuran & $\begin{array}{c}\text { Berat } \\
(\mathrm{Ka})\end{array}$ & $\begin{array}{c}\text { Ukuran }(\mathrm{cm}) \\
\mathrm{p} \times \mid \times t\end{array}$ & $\begin{array}{l}\text { Berat Isi } \\
\left(\mathrm{Ka} / \mathrm{m}^{3}\right)\end{array}$ \\
\hline$A$ & $0 \% \mathrm{Lcl}(1 \mathrm{Pc}: 2 \mathrm{Ps}: 3 \mathrm{Kr})$ & 8,12 & $15,11 \times 15,09 \times 15,25$ & 2335,5 \\
\hline$B$ & $\begin{array}{l}25 \% \mathrm{LCl}(1 \mathrm{Pc}:(11 / 2 \mathrm{Ps}+ \\
1 / 2 \mathrm{LCl}): 3 \mathrm{Kr})\end{array}$ & 8,09 & $15,12 \times 15,03 \times 15,17$ & 2346,7 \\
\hline C & 50\%(1Pc:(1Ps+1LCl): 3Kr) & 8,05 & $15,17 \times 15,04 \times 15,19$ & 2322,7 \\
\hline$D$ & $\begin{array}{l}75 \% \\
3 \mathrm{Kr})\end{array} \quad(1 \mathrm{Pc}:(1 / 2 \mathrm{Ps}+11 / 2 \mathrm{LCl})$ & 7,93 & $15,09 \times 15,06 \times 15,19$ & 2297,7 \\
\hline$E$ & $100 \%(1 \mathrm{Pc}: 2 \mathrm{Lcl}: 3 \mathrm{Kr})$ & 7,90 & $15,20 \times 15,16 \times 15,20$ & 2255,5 \\
\hline
\end{tabular}

\section{Pengujian kuat tekan beton}

Setelah dilakukan pengukuran dan penimbangan berat benda uji, maka langkah selanjutnya yaitu pengujian nilai kuat tekan beton atau benda uji. Hasil pengujian nilai kuat tekan beton atau benda uji dapat dilihat pada Tabel 3.

Tabel 3 Hasil Pengujian Nilai Kuat Tekan Beton Untuk Setiap Perlakuan

\begin{tabular}{|c|c|c|c|c|c|}
\hline No. & A & B & C & D & E \\
\hline 1. & 32,01 & 26,97 & 21,64 & 17,32 & 18,42 \\
2. & 32,89 & 25,97 & 20,64 & 16,35 & 19,60 \\
3. & 29,45 & 27,63 & 22,78 & 17,39 & 18,61 \\
4. & 31,81 & 26,57 & 22,81 & 16,77 & 19,00 \\
5. & 32,89 & 27,19 & 22,92 & 17,51 & 19,52 \\
6. & 33,24 & 27,88 & 23,36 & 18,76 & 19,52 \\
\hline
\end{tabular}




\begin{tabular}{|c|c|c|c|c|c|}
\hline No. & A & B & C & D & E \\
\hline 7. & 33,77 & 28,35 & 23,53 & 18,17 & 20,51 \\
8. & 35,54 & 28,96 & 23,09 & 18,33 & 20,79 \\
9. & 33,98 & 28,38 & 23,86 & 19,04 & 20,77 \\
10. & 35,74 & 30,08 & 24,94 & 19,74 & 21,71 \\
11. & 34,21 & 31,11 & 24,51 & 19,38 & 21,34 \\
12. & 34,86 & 30,00 & 24,45 & 19,73 & 20,91 \\
\hline R & $\mathbf{3 3 , 3 6}$ & $\mathbf{2 8 , 2 6}$ & $\mathbf{2 3 , 2 1}$ & $\mathbf{1 8 , 2 1}$ & $\mathbf{2 0 , 0 6}$ \\
\hline
\end{tabular}

Dari tabel diatas, terlihat bahwa kuat tekan beton perlakuan A dengan komposisi $0 \%$ limbah cetakan logam atau $1 \mathrm{Pc}$ : 2Ps : 3Kr mempunyai nilai kuat tekan tertinggi dibandingkan nilai kuat tekan perlakuan lainnya. Urutan nilai kuat tekan rata-rata berdasarkan urutan kelompok perlakuan terlihat pada Gambar 1.

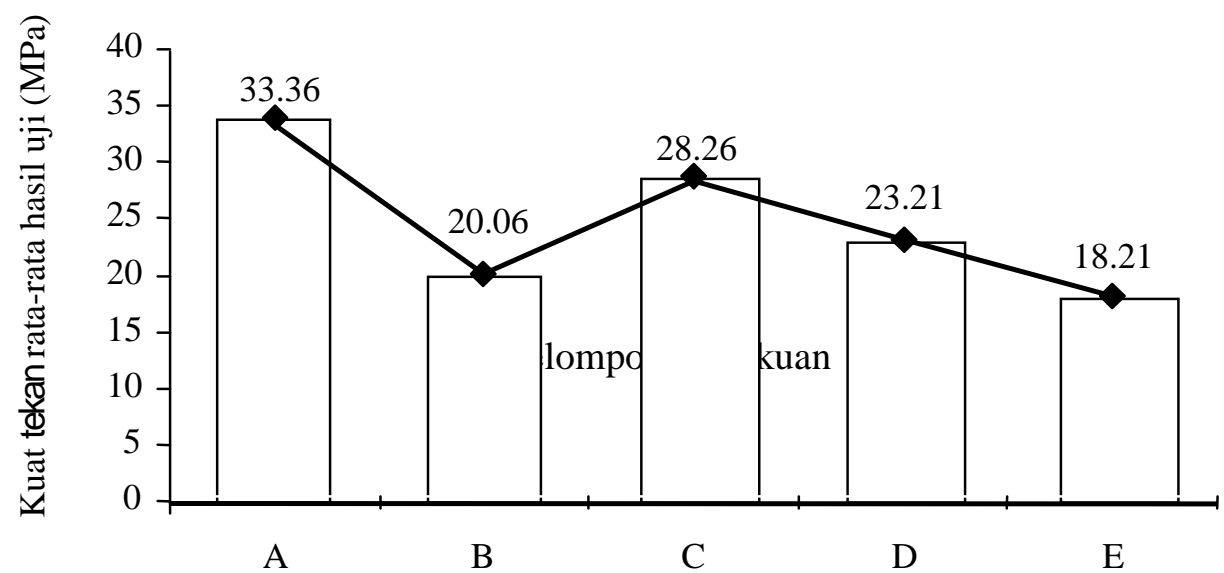

\section{Gambar 1, Hasil Uji Kuat Tekan Beton}

Dari gambar 1 diatas, dapat diambil kesimpulan yaitu: (1) Kandungan limbah cetakan logam yang semakin besar dalam campuran beton melalui uji tekan kubus maka akan semakin menurunkan nilai kuat tekan beton tersebut; (2) Nilai kuat tekan beton yang masih dianggap memenuhi syarat nilai untuk mutu K-225 MPa maka kandungan limbah cetakan logam dalam beton mempunyai komposisi 25\% limbah cetakan logam terhadap berat pasir atau $1 \mathrm{Pc}:(11 / 2 \mathrm{Ps}+1 / 2 \mathrm{LCl}): 3 \mathrm{Kr}$.

\section{Hubungan kuat tekan rata-rata beton uji dengan berat isi beton uji.}

Kuat tekan rata-rata hasil uji yang telah diperoleh tentunya masih ada kaitannya dengan berat isi benda tersebut. Sehingga kita perlu mengetahui seberapa besar hubungan diantara kuat tekan rata-rata hasil uji dengan berat isi. Kuat tekan rata-rata hasil uji dan berat uji untuk lebih jelasnya dapat dilihat pada Tabel 4. 
Tabel 4 Nilai Kuat Tekan Beton Uji Rata-Rata dan Berat Isi

\begin{tabular}{|c|c|l|l|l|}
\hline No. & $\begin{array}{c}\text { Kelomp } \\
\text { ok }\end{array}$ & \multicolumn{1}{|c|}{ Komposisi Campuran } & $\begin{array}{c}\text { Kuat tekan } \\
\text { Rata-rata } \\
(\mathrm{MPa})\end{array}$ & $\begin{array}{c}\text { Berat isi } \\
\left(\mathrm{Kg} / \mathbf{M}^{3}\right)\end{array}$ \\
\hline 1. & $\mathrm{~A}$ & $0 \% \mathrm{LCl}(1 \mathrm{Pc}: 2 \mathrm{Ps}: 3 \mathrm{Kr})$ & 33,36 & 2335,5 \\
2. & $\mathrm{~B}$ & $25 \% \mathrm{LCl}(1 \mathrm{Pc}:(11 / 2 \mathrm{Ps}+1 / 2 \mathrm{LCl}): 3 \mathrm{Kr})$ & 28,26 & 2346,7 \\
3. & $\mathrm{C}$ & $50 \% \mathrm{LCl}(1 \mathrm{Pc}:(1 \mathrm{Ps}+1 \mathrm{LCl}): 3 \mathrm{Kr})$ & 23,21 & 2322,7 \\
4. & $\mathrm{D}$ & $75 \%(1 \mathrm{Pc}:(1 / 2 \mathrm{Ps}+11 / 2 \mathrm{LCl}): 3 \mathrm{Kr})$ & 18,21 & 2297,7 \\
5. & $\mathrm{E}$ & $100 \%(1 \mathrm{Pc}: 2 \mathrm{LCl}: 3 \mathrm{Kr})$ & 20,06 & 2255,5 \\
\hline
\end{tabular}

Melihat nilai kuat tekan rata-rata beton uji dan berat isi, maka nilai kuat tekan rata-rata beton uji mengalami penurunan dan berat isi pun mengalami penurunan juga. Untuk lebih jelasnya hubungan kuat tekan rata-rata beton uji dan berat isi dapat dilihat pada Gambar 2.

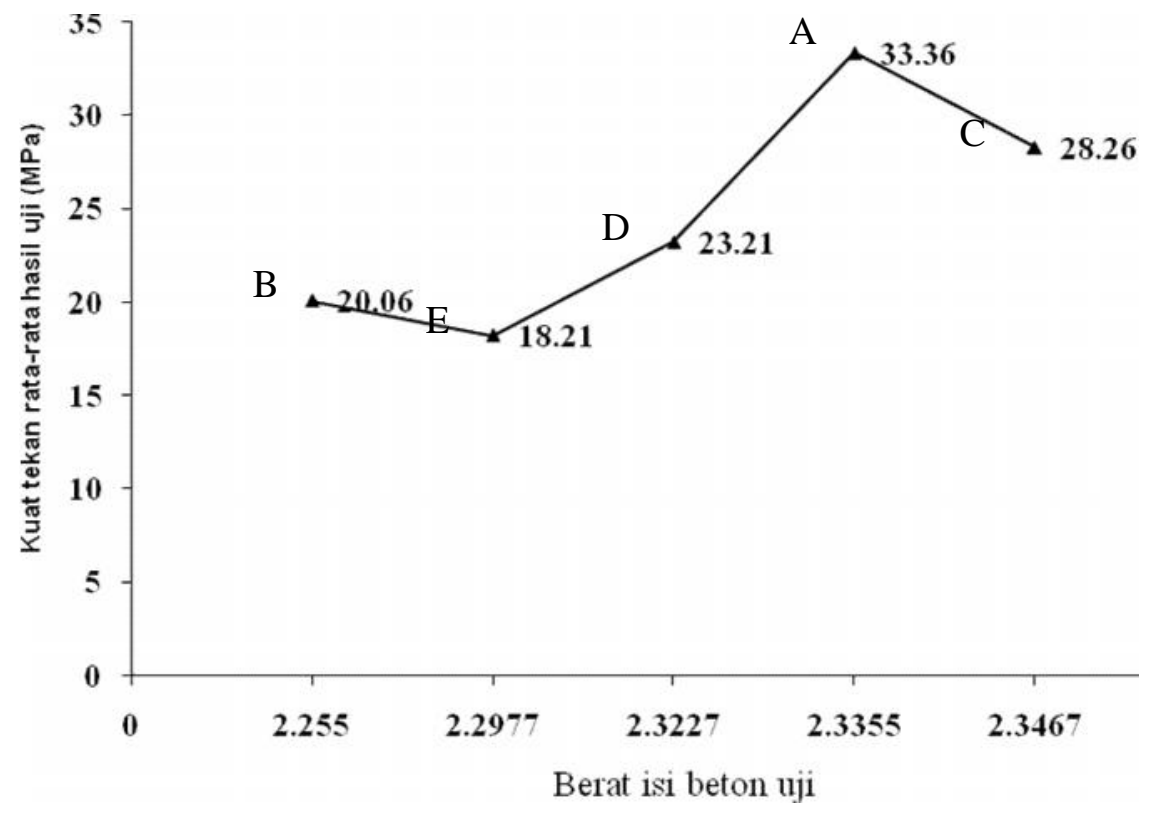

ar 2, Hubungan Kuat Tekan Rata-rata Beton Uji dan Berat Isi.

Gamb

Pada perlakuan A yang mempunyai nilai kuat tekan tertinggi $(33,36)$, ternyata mempunyai nilai berat isi beton uji yang signifikan (2,3355). Perlakuan D mengalami penurunan nilai kuat tekan $(23,21)$, maka mengalami pula penurunan nilai berat isinya $(2,3227)$. Perlakuan $E$ juga mengalami penurunan kuat tekan $(18,21)$ dan penurunan berat isi $(2,2977)$ daripada perlakuan $D$ dan perlakuan A. perlakuan B mengalami kenaikan nilai kuat tekan $(20,06)$ dan penurunan nilai berat isi $(2,2555)$, tetapi masih rendah nilai kuat tekan dan berat isi perlakuan $B$ dibandingkan nilai kuat tekan dan berat isi perlakuan D dan perlakuan A. Pada perlakuan C, mengalami penurunan nilai kuat tekan $(28,26)$ dibandingkan 
perlakuan A $(33,36)$, sedangkan berat isi perlakuan C $(2,3467)$ mengalami kenaikan dibandingkan perlakuan $\mathrm{A}(2,3355)$.

Dari gambar 2 diatas, maka dapat diambil kesimpulan bahwa semakin besar kamdungan limbah cetakan logam sebagai agregat halus dalam kuat tekan kubus beton, maka berat isi beton akan semakin turun.

\section{B. Pengujian Persyaratan Analisis Data}

\section{Uji normalitas}

Analisis statistik yang digunakan untuk menguji normalitas data adalah dengan menggunakan uji liliefors. Data yang dianalisis adalah data nilai kuat tekan beton benda uji dari masing-masing perlakuan.

\section{a. Uji normalitas data kuat tekan perlakuan $A$}

Hasil analisis data uji liliefors didapat nilai $L_{0}=0,2371$. Berdasarkan tabel nilai kritis uji liliefors untuk $n$ (sampel) $=12$ dan taraf signikan $(\alpha)=0,01$ diperoleh data $L_{\text {tabel }}=0,2750$. Maka nilai $L_{0}<L_{\text {tabel }}$ atau $0,2371<0,2750$ Kesimpulan dari hasil analisa diatas adalah bahwa data kuat tekan beton perlakuan $\mathrm{A}$ berdistribusi normal.

\section{b. Uji normalitas data kuat tekan perlakuan B}

Hasil analisis data uji liliefors didapat nilai $L_{0}=0,2202$. Berdasarkan tabel nilai kritis uji liliefors untuk $n$ (sampel) $=12$ dan taraf signikan $(\alpha)=0,01$ diperoleh data $L_{\text {tabel }}=0,2750$. Maka nilai $L_{0}<L_{\text {tabel }}$ atau $0,2202<0,2750$. Kesimpulan dari hasil analisa diatas adalah bahwa data kuat tekan beton perlakuan $\mathrm{C}$ berdistribusi normal.

\section{c. Uji normalitas data kuat tekan perlakuan C}

Hasil analisis data uji liliefors didapat nilai $L_{0}=0,2145$. Berdasarkan tabel nilai kritis uji liliefors untuk $n$ (sampel) $=12$ dan taraf signikan $(\alpha)=0,01$ diperoleh data $L_{\text {tabel }}=0,2750$. Maka nilai $L_{0}<L_{\text {tabel }}$ atau $0,2145<0,2750$ Kesimpulan dari hasil analisa diatas adalah bahwa data kuat tekan beton perlakuan $D$ berdistribusi normal.

\section{d. Uji normalitas data kuat tekan perlakuan D}

Hasil analisis data uji liliefors adalah nilai $L_{0}=0,2277$. Berdasarkan tabel nilai kritis uji liliefors untuk $n$ (sampel) $=12$ dan taraf signifikan $(\alpha)=0,01$ diperoleh data $L_{\text {tabel }}=0,2750$. Maka nilai $L_{0}<L_{\text {tabel }}$ atau 
$0,2277<0,2750$ Kesimpulan dari hasil analisa diatas adalah bahwa data kuat tekan beton perlakuan $\mathrm{E}$ berdistribusi normal.

\section{e. Uji normalitas data kuat tekan perlakuan $\mathrm{E}$}

Hasil analisis data uji liliefors didapat nilai $L_{0}=0,2148$. Berdasarkan tabel nilai kritis uji liliefors untuk $n$ (sampel) $=12$ dan taraf signikan $(\alpha)=0,01$ diperoleh data $L_{\text {tabel }}=0,2750$. Maka nilai $L_{0}<L_{\text {tabel }}$ atau $0,2148<0,2750$. Kesimpulan dari hasil analisa diatas adalah bahwa data kuat tekan beton perlakuan $B$ berdistribusi normal.

\section{Uji homogenitas}

Setelah persyaratan uji normalitas terpenuhi, maka selanjutnya uji homogenitas dengan menggunakan uji bartlett. Data yang diuji adalah data kuat tekan dari masing-masing kelompok perlakuan. Dari perhitungan diperoleh $\mathrm{X}^{2}$ hitung $=4,650$, jika taraf nyata $(\alpha)=0,01$ dari daftar Chi-kuadrat dengan $\mathrm{dk}=$ 11 didapat $X^{2}{ }_{\text {hitung }}<X^{2}$ tabel., maka dapat disimpulkan varians dari kelima kelompok tersebut homogeny

Tabel 5 Hasil Uji Homogenitas dengan Uji Bartlett.

\begin{tabular}{|c|c|c|c|c|}
\hline \multirow{2}{*}{ S2 Gabungan $^{*}$ Log S2 } & \multirow{2}{*}{ B } & \multicolumn{2}{|c|}{$\mathbf{X}^{2}$} \\
\cline { 4 - 5 } & & & Hitung & Tabel \\
\hline 1,712 & 0,2335 & 12,84 & 4,65 & 15,10 \\
\hline
\end{tabular}

\section{Pengujian Hipotesis}

\section{Hipotesis Pertama}

Untuk membuktikan hipotesis penelitian yang menyatakan terdapat perbedaan kuat tekan beton yang menggunakan limbah cetakan logam sebagai agregat halus dengan komposisi 0\%, 25\%, 50\%, 75\% dan 100\% limbah cetakan logam terhadap berat pasir maka digunakan analisa varians (ANAVA) satu arah.

Dari hasil perhitungan statistik yang telah dilakukan terhadap data yang diperoleh dengan $\mathrm{dk}$ pembilang $=4$ dan $\mathrm{dk}$ penyebut $=55$ serta peluang $0,99(\alpha=0,01)$ didapat $F_{\text {tabel }}=2,51$ sedangkan

$F_{\text {hitung }}=269,54$. Dengan demikian bahwa $F_{\text {hitung }}>F_{\text {tabel }}$ atau 269,54 $>2,51$. Kesimpulan hasil penelitiannya adalah terdapat perbedaan kuat tekan beton yang menggunakan limbah cetakan logam sebagai agregat halus dengan komposisi 0\%, 25\%,50\%,75\% dan 100\% limbah cetakan logam terhadap berat pasir 


\section{Hipotesis Kedua}

Untuk membuktikan hipotesis yang menyatakan bahwa kuat tekan beton yang menggunakan limbah cetakan logam sebagai agregat halus dengan komposisi 25\%, 50\%, 75\% dan 100\% limbah cetakan logam terhadap berat pasir lebih besar dari kuat tekan beton standar dengan komposisi $0 \%$ limbah cetakan logam terhadap berat pasir maka digunakan uji $\mathrm{T}$.

Tabel 6 Hasil Pengujian Kuat Tekan Rata-Rata Beton.

\begin{tabular}{|c|l|l|}
\hline Kelompok & \multicolumn{1}{|c|}{ Komposisi Campuran } & Hasil Pengujian (Mpa) \\
\hline A & $0 \% \mathrm{LCl}(1 \mathrm{Pc}: 2 \mathrm{Ps}: 3 \mathrm{Kr})$ & 33,36 \\
B & $25 \% \mathrm{LCl}(1 \mathrm{Pc}:(11 / 2 \mathrm{Ps}+1 / 2 \mathrm{LCl}): 3 \mathrm{Kr})$ & 28,26 \\
C & $50 \% \mathrm{LCl}(1 \mathrm{Pc}:(1 \mathrm{Ps}+1 \mathrm{LCl}): 3 \mathrm{Kr})$ & 23,21 \\
D & $75 \%(1 \mathrm{Pc}:(1 / 2 \mathrm{Ps}+11 / 2 \mathrm{LCl}): 3 \mathrm{Kr})$ & 18,21 \\
E & $100 \%(1 \mathrm{PC}: 2 \mathrm{LCl}: 3 \mathrm{Kr})$ & 20,06 \\
\hline
\end{tabular}

Dari hasil pengujian kuat tekan rata-rata beton dapat disimpulkan bahwa kelompok $\mathrm{A}>\mathrm{B}>\mathrm{C}>$ $E>D$. Sehingga berdasarkan hasil rata-rata pengujian diatas kelompok $A$ dengan komposisi $0 \%$ limbah cetakan logam terhadap berat pasir atau 1Pc : 2Ps : 3Kr sebagai beton standar yang tanpa menggunakan limbah cetakan logam sebagai agregat halus lebih tinggi dari kelompok perlakuan lainnya yang menggunakan limbah cetakan logam sebagai agregat halus.

Dengan perhitungan statistik terhadap data yang diperoleh diketahui $\mathrm{dk}=11$ dengan taraf nyata 0,01 diperoleh $T_{\text {tabel }}=2,68$. Sehingga syarat penerimaan terhadap hipotesis II ini adalah menolak $\mathrm{H}_{0}$ jika $T_{\text {hitung }} \geq T_{\text {tabel. }}$. Uji T untuk hipotesis II, $H_{1}: \mu_{B}>\mu_{A}$ didapat $T_{\text {hitung }}=7.907$, karena $T_{\text {hitung }} \geq T_{\text {tabel }}$ maka $\mathrm{H}_{0}$ dan $\mathrm{H}_{1}$ ditolak dalam taraf nyata 0,01 . Jadi dapat dikatakan bahwa kuat tekan beton yang menggunakan limbah cetakan logam sebagai agregat halus dengan komposisi $25 \%$ limbah cetakan logam terhadap berat pasir atau perbandingan 1Pc : (11/2 Ps + 1/2Lcl) : 3Kr lebih rendah dari kuat tekan beton standar dengan komposisi $0 \%$ limbah cetakan logam atau perbandingan $1 \mathrm{Pc}: 2 \mathrm{Ps}: 3 \mathrm{Kr}$. Uji T untuk hipotesis II, $\mathrm{H}_{1}: \mu_{\mathrm{C}}>\mu_{\mathrm{A}}$ didapat $\mathrm{T}_{\text {hitung }}=17,41$, karena $\mathrm{T}_{\text {hitung }} \geq \mathrm{T}_{\text {tabel }}$ maka $\mathrm{H}_{0}$ dan $\mathrm{H}_{1}$ ditolak dalam taraf nyata 0,01 . Jadi dapat dikatakan bahwa kuat tekan beton yang menggunakan limbah cetakan logam sebagai agregat halus dengan komposisi $50 \%$ limbah cetakan logam terhadap berat pasir atau perbandingan $1 \mathrm{Pc}:(1 \mathrm{Ps}+1 \mathrm{Lcl}): 3 \mathrm{Kr}$ lebih rendah dari kuat tekan beton standar dengan komposisi $0 \%$ limbah cetakan logam atau perbandingan $1 \mathrm{Pc}: 2 \mathrm{Ps}: 3 \mathrm{Kr}$. Uji T untuk hipotesis $\mathrm{Il}, \mathrm{H}_{1}: \mu_{\mathrm{D}}$ $>\mu_{A}$ didapat $T_{\text {hitung }}=25,08$, karena $T_{\text {hitung }} \geq \mathrm{T}_{\text {tabel }}$ maka $\mathrm{H}_{0}$ dan $\mathrm{H}_{1}$ ditolak dalam taraf nyata 0,01 . Jadi dapat dikatakan bahwa kuat tekan beton yang menggunakan limbah cetakan logam sebagai agregat halus dengan komposisi $75 \%$ limbah cetakan logam terhadap berat pasir atau perbandingan $1 \mathrm{Pc}$ : $(1 / 2 \mathrm{Ps}+11 / 2 \mathrm{LCl}): 3 \mathrm{Kr}$ lebih rendah dari kuat tekan beton standar dengan komposisi 0\% limbah cetakan logam atau perbandingan $1 \mathrm{Pc}: 2 \mathrm{Ps}: 3 \mathrm{Kr}$. Uji T untuk hipotesis $\mathrm{Il}, \mathrm{H}_{1}: \mu_{\mathrm{E}}>\mu_{\mathrm{A}}$ didapat $\mathrm{T}_{\text {hitung }}=$ 
22,41, karena $T_{\text {hitung }} \geq \mathrm{T}_{\text {tabel }}$ maka $\mathrm{H}_{0}$ dan $\mathrm{H}_{1}$ ditolak dalam taraf nyata 0,01 . Jadi dapat dikatakan bahwa kuat tekan beton yang menggunakan limbah cetakan logam sebagai agregat halus dengan komposisi $0 \%$ limbah cetakan logam atau perbandingan $1 \mathrm{Pc}: 2 \mathrm{Lcl}: 3 \mathrm{Kr}$ lebih rendah dari kuat tekan beton standar dengan komposisi $0 \%$ limbah cetakan logam atau perbandingan $1 \mathrm{Pc}: 2 \mathrm{Ps}: 3 \mathrm{Kr}$.

Kesimpulan terhadap hipotesis II bahwa kuat tekan beton yang menggunakan limbah cetakan logam sebagai agregat halus dengan komposisi 25\%, 50\%, 75\% dan 100\% limbah cetakan logam terhadap berat pasir lebih lebih rendah dari kuat tekan beton standar dengan komposisi $0 \%$ limbah cetakan logam atau perbandingan $1 \mathrm{Pc}: 2 \mathrm{Ps}: 3 \mathrm{Kr}$.

\section{Pembahasan Hasil Penelitian}

1. Penggunaan limbah cetakan logam sebagai agregat halus pada kuat tekan beton sangat mempengaruhi nilai kuat tekannya, sehingga dari lima kelompok perlakuan tersebut mempunyai beberapa nilai kuat tekan yang cukup jauh berbeda. Dengan komposisi tersebut diketahui seberapa jauh dan besar pengaruh pemakaian limbah cetakan logam sebagai agregat halus. Ternyata dari lima kelompok perlakuan tersebut mengalami penurunan kuat tekan rata-rata sebesar $\pm 3,78 \mathrm{MPa}$ untuk antar perlakuannya.

Kelompok A sebagai kelompok perlakuan yang tanpa menggunakan limbah cetakan logam sebagai agregat halus tapi menggunakan pasir mundu yang berfungsi sebagai beton standar menghasilkan nilai kuat tekan yang paling tinggi yaitu sebesar 33,36 MPa. Kelompok B yang menggunakan limbah cetakan logam sebagai agregat secara penuh pada kuat tekan beton mempunyai nilai kuat tekan sebesar 20,06 MPa. Kelompok $\mathrm{C}$ yang menggunakan limbah cetakan logam dan pasir sebagai agregat halus sebesar 1/2 Lcl dan 11/2 Pasir mempunyai nilai kuat tekan sebesar 28,26 MPa. Kelompok $\mathrm{D}$ yang menggunakan limbah cetakan logam dan pasir sebagai agregat halus dengan perbandingan $1 \mathrm{Ps}$ dan $1 \mathrm{Lcl}$ mempunyai nilai kuat tekan beton sebesar 23,21 MPa. Kelompok $\mathrm{E}$ yang menggunakan limbah cetakan logam dan pasir sebagai agregat halus dengan perbandingan 11/2LCl dan 1/2 mempunyai nilai kuat tekan sebesar 18,21 MPa.

Dari lima kelompok diatas ternyata kelompok $A$ sebagai beton standar yang tanpa menggunakan limbah cetakan logam sebagai agregat halus mempunyai nilai kuat tekan yang paling tinggi. Tetapi kalau kita bandingkan dengan nilai kuat tekan minimum beton mutu K-225 maka kelompok A, kelompok $C$ dan kelompok $D$ mempunyai nilai diatas kuat tekan minimum beton mutu K-225, sedangkan kelompok $\mathrm{B}$ dan kelompok $\mathrm{E}$ mempunyai nilai dibawah kuat tekan minimum beton mutu K-225. Kesimpulannya semakin banyak limbah cetakan logam digunakan sebagai agregat halus pada beton, maka akan semakin mengurangi nilai kuat tekan beton tersebut. 
2. Kuat tekan beton standar yang menggunakan pasir sebagai agregat halus ternyata masih lebih tinggi bila dibandingkan kuat tekan beton yang menggunakan limbah cetakan logam sebagai agregat halusnya. Dari penelitian didapat nilai rata-rata kuat tekan beton yang tertinggi pada komposisi $1 \mathrm{Pc}$ : 2Ps : $3 \mathrm{Kr}$ dengan nilai kuat tekan sebesar 33,36 MPa. Nilai yang terendah terdapat pada komposisi 1Pc : 2Lcl : 3Kr dengan nilai kuat tekan sebesar 18,21 dan komposisi $1 \mathrm{Pc}:(1 / 2 \mathrm{Ps}+11 / 2 \mathrm{LCl}): 3 \mathrm{Kr}$ dengan nilai kuat tekan sebesar 20,06.

Tentunya dengan nilai terendah tersebut sudah tidak memenuhi nilai kuat tekan beton minimum untuk mutu K-225. Pada komposisi $1 \mathrm{Pc}: 2 \mathrm{Ps}: 3 \mathrm{Kr}, 1 \mathrm{Pc}:(11 / 2 \mathrm{Ps}+1 / 2 \mathrm{Lcl}): 3 \mathrm{Kr}$ dan 1Pc : (1Ps + $1 \mathrm{Lcl}): 3 \mathrm{Kr}$ masih memenuhi nilai kuat tekan beton minimum beton SNI $\left(22,5 \mathrm{Kg} / \mathrm{cm}^{2}\right)$ pada taraf nyata 0,01 . Dengan demikian maka limbah cetakan logam ini tidak bisa digunakan sebagai agregat halus kecuali untuk struktur beton ringan.

\section{E. Keterbatasan Penelitian}

Peneliti sangat menyadari bahwa sebagai salah satu insan manusia tidak bisa lepas dari apa yang namanya sebuah kekuarangan. Sehingga penelitian ini juga masih banyak kekurangan yang tentunya membutuhan sebuah kelengkapannya atau kekurangannya. Tetapi peneliti pun sudah se-optimal mungkin untuk mengerjakan dan menyelesaikan penelitian ini sebaik mungkin, walaupun tetap masih ada kelemahannya. Adapun salah satu kekuraangannya adalah antara lain :

1. Ketika penelitian mengenai bahan-bahan penyusun beton dan limbah ini tidak selalu menghasilkan nilai yang sama antara pekerjaan yang satu dengan yang lainnya.

2. Pada pembuatan benda uji tidak selalu akurat tentang perbandingannya antara bahan-bahan penyusun beton, karena hanya dilakukan penelitian pada mutu beton f'c 22,5 MPa.

3. Pengukuran benda uji tidak selalu tepat, ini dikarenakan tidak selalu sama perbedaan-perbedaan pada tiap benda uji.

4. Pengujian ini hanya memakai umur beton 28 hari dan hanya diuji pada nilai kuat tekannya.

\section{KESIMPULAN}

Berdasarkan hasil penelitian yang telah dilakukan, maka dapat diambil kesimpulan yaitu:

1. Semakin tinggi kandungan limbah cetakan logam sebagai agregat halus pada kuat tekan beton, maka mutu kuat tekan beton tersebut cenderung turun yang diikuti penurunan berat isi beton.

2. Penggunaan limbah cetakan logam sebagai bahan substitusi pengganti agregat halus pada kuat tekan beton yang baik dan memenuhi standar mutu K-225 hanya campuran 0\%, 25\% dan 50\% limbah cetakan logam terhadap berat pasir. 


\section{DAFTAR PUSTAKA}

Amos Neolaka, 1986. Pengantar Penelitian Pendidikan. Grasindo Utama, Jakarta

Chu Kia Wang, Charles G. Salmon, Binsar Hariandja, 1993. Desain Beton Bertulang. Erlangga. Jakarta

Dinamika Teknik Sipil, Volume I, Nomor 2, Juli 2001

Eddy Sukardi, Tanudi, 1997. Membuat Bahan Bangunan Dan Sampah. Puspa Swara. Jakarta.

Edward G. Nawy, 1990. Beton Bertulang Suatu Pendekatan Dasar._PT.ERESCO. Bandung.

Elly Madyayanti, 1992. Seri Pedoman Mekanika Tanah._Erlangga. Djakarta

IK. Supribadi, 1986. IImu Bangunan Gedung Seri A._CV. ARMICO. Bandung.

Istimawan Dipohusodo, 1996. Struktur Beton Bertulang. PT. Gramedia Pustaka Utama. Jakarta

J.Kwantes,J.Klaveren, P. Diraatmadja, 1987. IImu Bangunan. Erlangga. Jakarta.

Jurnal Teknik Sipil dan Perencanaan, Volume IV, Nomor 1, Januari 2002

Jurnal Teknik, Volume III Nomor 5, September 1996

Kusuma, G. 1994. Pedoman Pengerjaan Beton. Erlangga. Jakarta.

Lawrence H. Van Vlack, Sriati Djafrie. 1992. Ilmu dan Tenologi Bahan. Erlangga. Jakarta.

M. Nasir Arsyad, 2001. Kamus Kimia Inti dan Penjelasan Istilah. PT. Gramedia Pustaka Utama. Jakarta

Murdock, L.J, K.M. Brook. 1986. Bahan dan Praktek Beton. Erlangga. Jakarta.

Persyaratan Umum Bahan Bangunan Indonesia, 1982, PUBBI

Sudjana, 1996. Metoda Statistika. Penerbit Tarsito. Bandung.

Rivera, R. 1995. Air Entrainning Admixture Application of Admixtures in Concrete,_(E \& FN SPON,)

S.M. Ritonga, 1986. Bahan Bangunan. Departemen Pekerjaan Umum, LPMB. Jakarta.

Tata Surdia, Kenji Chijiiwa, 1980. Teknik Pengecoran Logam. PT.Pradnya Paramita. Jakarta

Tjokrodimuljo,K. 1996. Teknologi Beton. PT. Nafiri. Yogyakarta

Wawan Witarnawan, 1985. Konstruksi Beton. Departemen Pekerjaan Umum, Badan Penelitian dan Pengembangan Pekerjaan Umum, Pusat Penelitian dan Pengembangan Jalan. Bandung.

Wuryati Sawekto, Candra Rahmadiyanto. 2001. Teknologi Beton. Kanisius. Yogyakarta 